\title{
Letter to the Editor: Lack of Mitochondrial Enzymes of the Urea Cycle in Human White Blood Cells
}

\author{
D. RABIER, L. CATHELINEAU, AND P. KAMOUN
}

Laboratoire de Biochimie Génétique, Hôpital Necker, 75731 Paris Cedex 15, France

Wolfe and Gatfield (13) recently described the presence of the urea cycle mitochondrial enzymes in leukocytes: ornithine carbamoyltransferase (EC. 2.1.3.3) and acetylglutamate-dependent carbamoylphosphate synthetase (EC. 2.7.2.5). They also proclaimed that assays in leukocytes might be useful in diagnosing hereditary deficiencies of these two enzymes. With the same aim in mind, we tried to reproduce these experiments.

Human leukocytes were prepared according to the method of Wolfe and Gatfield (13) or of Allard et al. (1), human peripheral lymphocytes were prepared according to the method of Boyum (3) on a Ficoll-Triosil mixture, and in some experiments phytohemagglutinin-stimulated lymphocytes were also investigated.

In all cases, cells were destroyed at $4^{\circ}$ in $1 \mathrm{ml}$ cetyltrimethylammonium bromide $(0.1 \%) ; 1 \mathrm{ml}$ of the centrifugation supernatant $(150 \mathrm{sec}$ at $12,000 \times \mathrm{g})$ was incubated for $5 \mathrm{~min}$ at $37^{\circ}$ with oxyaminoacetic acid ( $1.5 \mathrm{mM}$ ) to inhibit ornithine-ketoacid transaminase activity (9).

Ornithine carbamoyltransferase was assayed in three different ways: 1) according to the method of Wolfe and Gatfield (13) where citrulline is measured according to the method of Archibald (2); 2) according to the method of Snodgrass and Parry (I1), with citrulline being assayed according to the method of Ceriotti and Spandrio (5); and 3 ) by an isotopic method, using the same reaction mixture as Wolfe and Gatfield (13) and with $L\left[G^{-}{ }^{3} \mathrm{H}\right]-$ ornithine $(20 \mu \mathrm{Ci}) .\left[{ }^{3} \mathrm{H}\right]$ Citrulline formed is measured after high voltage electrophoresis (formic acid-acetic acid buffer, pH 1.9, 60 $\mathrm{v} / \mathrm{cm}, 40 \mathrm{~min}$ ).

Carbamoylphosphate synthetase I was measured exclusively by isotopes, using Brown and Cohen's (4) reaction mixture buffered with sodium phosphate $(60 \mathrm{mM})$, with and without acetylglutamate: the mixture contained $L\left[G-{ }^{3} \mathrm{H}\right]$-ornithine $(20 \mu \mathrm{Ci})$. (8).

Proteins were assayed according to the method of Lowry et al.

To measure ornithine carbamoyltransferase activity, $0.1-0.6 \mathrm{mg}$ cell proteins were used by sample, which, according to Wolfe and Gatfield, corresponds to a production of 26-156 nmoles of citrulline in 2 hr at $37^{\circ}$. None of the different methods used ( 12 assays in all) allowed a recovery of citrulline formed greater than the one due to the spontaneous carbamylation of omithine by carbamoylphosphate (11). Nonetheless, isotopic methods allow us to quantitate less than 2 nmoles of citrulline. Lymphocytes are not distinguished from total leukocytes. Stimulation by phytohemagglutinin allows no induction of a normally lacking enzyme synthesis in the circulating lymphocytes, as has been described, for instance, for cystathionine synthetase (6).

Likewise, the carbamoylphosphate synthetase activity measured is remarkably insensitive to acetylglutamate. The activity measured is in fact that of glutamine-using carbamoylphosphate synthetase, of which the presence was indicated by Ito and Uchino (7) in peripheral lymphocytes.

Our results are therefore in deep disagreement with those of Wolfe and Gatfield (13), but agree with those of Spector (12) on human lymphocytes. According to the method of Wolfe and Gatfield, incubations are made in glycylglycine buffer, originating in a very high reactive blank. Referred to such a blank, very slight variations of optical density make the interpretation of the results most arduous.

\section{REFERENCES AND NOTES}

I. Allard, D. Parvy, P., Castets, J. C., Huang Y, and Kamoun, P.: Assay of tissue free-cystine: application to the diagnosis of cystinosis. Ann. Clin. Biochem. 15: (6) (1978)

2. Archibald. R. M.: Determination of citrulline and allantoine and demonsltation of citrulline in blood plasma. J. Biol. Chem., /56: 121 (1944).

3. Boyüm, A.: Separation of leucocytes from blood and bone marrow, J. Clin. Lab. Invest. Suppl, 97: 21 (1968).

4. Brown, Jr., G. W., and Cohen, P. P.: Comparative biochemistry of urea synthesis. I. Methods for the quantitative assay of urea cycle enzymes in liver. J. Biol. Chem. 234: 1770 (1959).

5. Ceriotti,, $\mathbf{G}$, and $\$$ pandrio, $\mathbf{L}$.: Catalytic acceleration of the urea-diacelylmonoxime phenazone reaction and its application to automatic analysis. Clin. Chim. Ac1a, II: 519 (1965).

6. Goldstein, J. L., Campbell, B. K., and Cartler, S. M.: Cystathionine synthetase activity in human lymphocytes: Induction by phyrohemagglutinin. J. Clin. Invest. 5/: 1034 (1972).

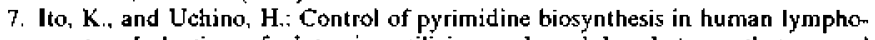
cytes. Induction of glutamine-utilizing carbamylphosphate synthetase and operation of orolic acid pathway during blastogenesis. J. Biol. Chem., 246: 4060 (197J).

8. Lowry, O. H., Rosebrough, N. H., Fart, A. L. and Randall, R.: Protein measurement with the Folin phenol reagent. J. Biol. Chem.. 193: 265 (1951).

9. McGivan. J. D., Bradford. N. M., and Beavis, A. D.: Factors influencing the activity of ornithine aminotransferase in isolated rat liver mitochondria. Biochem. J., 162: 147 (1977).

10. Smith, L. H., Jr., and Baker, F. A.: Pyrimidine metabolism in mart. I. The biosynthesis of orotic acid. J. Clin. lnvest., 38: 798 (1959).

II. Snodgrass, P. J., and Parry, D. J.: The kinelics of serum ornithine carbamoyltransferase. J. Lab. Clin. Med. 73:940 (1969).

12. Spector, E. B.: Citrullinemia: the study of an hereditary inborn error of metabolism in human long-term lymphocyte lines. Diss. Abstr., 35:5256 (1975).

13. Wolfe, D. M., and Galfield, P. D. Leukocyte urea cycle enzymes in hyperarnmonemia. Pediatr. Res., 9: 531 (1975). 